\title{
Effect of Adding Tartaric and Salicylic Acids and Their Mixture to Water and Diet in Egg Quality Characteristics of Aged Laying Hens
}

\author{
Ammar Taleb Dhiab ${ }^{\text {ID }}$, Younus Abbas Khalaf Al-Saadi ${ }^{2}$ \\ ${ }^{I}$ Dept. Animal Production - Agriculture of college-University of Diyala-Iraq, \\ ${ }^{2}$ Directorate of Agriculture in Diyala governorate, Ministry of Agriculture, Iraq \\ Corresponding Author: younis.abbas1977@gmail.com, \\ Ammaraltememy@uodiyala.edu.iq
}

Article history:
Received 16 June 2021
Accepted 27 July 2021

keyword : Tartaric acid, Salicylic acid, Water, Diet, Aged laying hens, Egg quality.

\begin{abstract}
The study aimed to know the effect of adding tartaric and salicylic acids alone and a mixture of water and diet on the egg quality characteristics of aged laying hens for brown Lohmann. 210 laying hens 60 weeks old were used The duration of the experiment, which lasted 112 days(16 weeks), was divided into four equal periods at a rate of 28 days for each period,, distributed in equal numbers to 21 ground hens, 10 laying hens for each hen, and distributed to seven treatments with three replications of the treatment, T1 was fed a standard diet without adding (control), T2 was fed a standard diet supplemented with $0.2 \%$ tartaric acid with water, T3 was fed a standard diet supplemented with $0.2 \%$ salicylic acid with water, $\mathrm{T} 4$ was fed a standard diet supplemented with $0.4 \%$ tartaric acid and salicylic acid was added with water, T5 was fed a standard diet supplemented with $\% 0.2$ tartaric acid in the diet, T6 was fed a standard diet supplemented with $0.2 \%$ salicylic acid in the diet, $\mathrm{T} 7$ was fed a standard diet supplemented with $0.4 \%$ a mixture of tartaric and salicylic acid in the diet. The results of adding the two acids in the water and feed showed that there was a significant improvement $(\mathrm{P} \leq 0.01)$ in the quality characteristics of the eggs produced, as it significantly improved the shell weight, shell thickness, albumin height, albumin weight, Haugh unit, rate of yolk height, yolk weight, and the yolk diameter was significantly reduced for the coefficients of The addition compared with the control treatment.

* This research is part of M.Sc. thesis of the second researcher.
\end{abstract}

\section{Introduction}

The qualitative characteristics of the eggs produced are subject to deterioration as the birds progress in their productive life and reach the peak of production, and the reason for this is that the body organs are subjected to fatigue, especially the organs that have to do with the ability of the bird to produce and are represented by the activity of the digestive and reproductive systems (Qu et al., 2018; Liu et al., 2020). Therefore, researchers and specialists directed towards improving the perseverance and prolonging the productive life of the laying poultry flocks by finding and developing modern crosses for laying hens breeds, and the use of balanced feed rations as well as the use of feed additives that stimulate the health and production of these camels, especially the additives affecting the improvement of the environment and health of the alimentary canal in order to increase The economic return of these herds (Nevling, 2018).

Antibiotics have been used as additives to poultry feeds for a long time because of their beneficial effect in eliminating harmful microbes and improving bowel health, but the use of these antibiotics has become a matter of great controversy in recent years due to the emergence of bacterial strains resistant to these antibiotics as well as their potential damage to human health ( Ye and others, 2020) and this is what prompted researchers to search for natural and safe food additives, the most 
important of which are organic acids, probiotics, enzymes and other food additives including medicinal herbs (AL-Khalaifah, 2018; AL-Gharawi et al., 2018).

Organic acids are considered good alternatives to antibiotics, as they have been used as growth stimulants in poultry diet because of their stimulating effect on beneficial bacteria, inhibiting or eliminating some types of harmful bacteria, and improving the internal quality of their eggs, as well as improving the digestive activity of their eggs. Feeds protect them from rotting and prevent infection with some types of fungi (Wang et al., 2009; Kaya et al., 2014; Jasim and Taha, 2017; Attia et al., 2018; Bansod et al., 2020).Short-chain fatty acids contain 4-6 carbon atoms and are always saturated, such as butyric acid, and have an antibacterial effect. As for medium chain fatty acids, they contain 8-12 carbon atoms, and lauric acid is an example, which has antiviral and antibacterial properties. are antimicrobial and antioxidant, improve digestion, enhance intestinal function by increasing mucosal secretion, and improve bird health (Hassan and Al-Timimi, 2017; Abdelli et al., 2020).

Among the organic acids used as feed additives is tartaric and salicylic acid, which are considered natural organic acids, Tartaric acid, which is aliphatic acid, is found in many fruits, including grapes, bananas, and tamarind, and it is considered an antimicrobial. As for salicylic acid, it is an aromatic acid and is found in the willow plant, so it is called salicylic acid and is considered an antiinflammatory and antipyretic. (The Chemical Company, 2010). This study aimed to show the effect of adding tartaric and salicylic acids to the drinking water and feed for laying hens on the egg quality characteristics..

\section{Materials and Methods Ethical Approval}

Experimental animal: all applicable national and internationnal guidelines for the care and use of animals were followed.

This study was conducted in the poultry field of the Department of Animal Production / College of Agriculture / Diyala University for a period from $1 / 11 / 2020$ to $20 / 2 / 2021$ for a period of 16 weeks, during which the effect of adding tartaric acid and Salicylic acid was studied in water and feed on the productive performance of aged laying hens of the brown Lohmann type.
In this study, 210 laying hens of Lohmann Brown breed at 58 weeks of age were used, The duration of the experiment, which lasted 112 days(16 weeks), was divided into four equal periods at a rate of 28 days for each period, After two weeks of adapting to the conditions and diets of the experiment, the experiment started at the age of 60 weeks (beginning of the experiment). The weight of the chickens individually was $1800 \mathrm{~g} \pm 10 \%$ of the standard weight, then randomly distributed On seven treatments with three replicates per treatment, one replicate contained 10 laying hens and the first and second weeks were considered between 58 and 59 weeks of chicken life is an introductory period for normalizing the chickens on the atmosphere of the hall, manholes, manholes and egg-laying nests. During the preliminary period, the chickens were fed a standard diet Table (1) that contained all the required nutrients according to the recommendations of the company that produced this race. This relationship was used as a comparison for the proposed treatments under study, and the study included seven treatments, which are in the order below.

T1: Control treatment a standard diet was used without adding the length of the experiment.

T2: fed on a standard diet supplemented with $0.2 \%$ of tartaric acid in water.

T3: fed a standard diet supplemented with $0.2 \%$ salicylic acid with water.

T4: fed on a standard diet supplemented with a mixture of $0.4 \%$ of organic acids with water.

T5: fed on a standard diet supplemented with $0.2 \%$ of tartaric acid in the feed.

T6: fed a standard diet supplemented with $0.2 \%$ salicylic acid in the feed.

T7: fed on a standard diet supplemented with a mixture of organic acids $(0.4 \%)$ in the feed.

The addition treatments were prepared for successive periods, and the period between each preparation and the last two weeks was in order to maintain the effectiveness of the added organic acids during this period, as the oil was first added to the feed and then the organic acids were mixed with the feed manually with a small amount of feed and then gradually increased in order to obtaining the required homogeneity (the necessary health precautions were taken when mixing the organic acids with the feed material) and then mixed with 
the rest of the feed until the required homogeneity was reached between the meal of the feed material, as well as these acids were manually mixed with a small amount of water and then gradually increased in order to obtain homogeneity. What is required is between water and acid, and mixing acids with water was weekly, After the completion of the mixing, it was packed in sealed plastic containers marked each according to the treatment to which it belongs, and was careful to close the containers even when providing feed and water to the chickens to maintain the effectiveness of the organic acids added to the feed and water as the effect of the added organic acids remains effective for a month when conditions are available suitable storage (Iba and Jr, 1995).

Table 1. Ingredients (\%) and chemical composition of the diets used in the Experiment

\begin{tabular}{|c|c|}
\hline The components of the diet & The ratio \% \\
\hline yellow corn & 40 \\
\hline wheat $^{\text {Soybean gain }}{ }^{(1)}$ & 27.5 \\
\hline Premix $^{(2)}$ & 20 \\
\hline Limestone & 2.5 \\
\hline Di-Calcium Phosphate & 1 \\
\hline cooking oil & 1 \\
\hline Total & 100 \\
\hline Calculated chemical composition & $\mathbf{( 3 )}$ \\
\hline Crude protein $\%$ & 15.86 \\
\hline Metabolic energy (kcal / kg feed) & 2734 \\
\hline C : P Ratio & 172.4 \\
\hline Methionine\% & 0.40 \\
\hline Methionine and cysteine\% & 0.70 \\
\hline Lysine\% & 0.80 \\
\hline Calcium\% & 3.44 \\
\hline Available phosphorus\% & 0.59 \\
\hline
\end{tabular}

(1) The soybean meal used from an Argentine source, it contained $44 \%$ crude protein and represented an energy of 2230 kilocalories $/ \mathrm{kg}$.

(2) Use the Nuscience premix produced by the Dutch company Agrifirm, which contains $20 \%$ protein, energy represented $4188 \mathrm{kcal} / \mathrm{kg}$, lysine $3 \%$, methionine $6.46 \%$, methionine and cysteine $7.80 \%$, threonine $2.65 \%$, valine $1.93 \%$, arginine $1.65 \%$, calcium $9.77 \%$, available phosphorus
$9.08 \%$, sodium $6 \%$ and all the trace minerals and vitamins required for laying hens.

(3) The chemical composition of the diets was calculated according to the analyzes of forage materials contained in the reports of the US National Research Council (NRC, 1994).

Tartaric acid and salicylic acid were obtained from one of the scientific offices in Baghdad, England production, with a concentration of $99.5 \%$ for both acids, and the acids were solid. Statistical analysis of the experimental data was carried out using a complete random design (CRD) in analyzing the data between the averages of the coefficients for each period. As for the total data during the entire period, the complete randomized design (RCBD) was used. To test the significance of the differences between the means of the coefficients, the Tukey's test was used, at the level of significance 0.05 , and the ready-made statistical program SAS (2001) was used to analyze the data.

\section{Measuring of Qualitative Characteristics}

As the measurement was carried out according to the methods indicated by Fayyad and Naji (2010).

\section{Shell Weight}

The weight of the shell was measured after breaking it directly with the membranes by using a sensitive scale for a purpose that reads to the nearest two decimal places and the unit of measurement was grams.

\section{Thickness of the Shell}

The thickness of the shell and the inner membranes were measured after leaving it for 48 hours to dry from the pointed and wide ends of each egg by means of a macrometer and the average of the two readings was taken.

Shell thickness ratio $(\mathrm{mm})=$ Shell Thickness from Wide $(\mathrm{mm})+$ Shell Thickness from Pointed End $(\mathrm{mm}) / 2$.

\section{Albumin High}

This characteristic was measured by means of a special triple-base micrometer device and the unit of measure (mm) was measured from two points facing the thick white, and the average of the two readings was taken for the whiteness of each egg.

\section{Albumin Weight}


The weight of the albumin (g) was calculated by subtracting the weight of the yolk and the weight of the shell from the weight of the egg.

Albumin weight $(\mathrm{g})$ = egg weight $-($ yolk weight + shell weight).

\section{Haugh Unit}

To extract a unit (Haugh unit), measure the weight of an egg (g) using a sensitive balance as well as measure the height of the thick white $(\mathrm{mm})$, by applying the equation mentioned by Al-Fayyad and Naji (1989):

\section{Haugh unit $=100 \log \left(\mathrm{H}+7.57-1.7 \mathrm{~W}^{0.37}\right)$ \\ $\mathrm{H}=$ egg height $(\mathrm{mm})$ and $\mathrm{W}=$ egg weight $(\mathrm{g})$. \\ Yolk Height}

Yolk height $(\mathrm{mm})$ was measured using a triplebase micrometer and the height of the yolk was taken from the highest point.

\section{Diameter of The Yolk}

The diameter of the yolk was measured using an electronic furnace machine, and the unit of measure was the millimeter, where the measurement was taken from two points opposite to the yolk, and the average of the two readings was taken for the yolk of each egg.

\section{Yolk Weight}

The yolk was weighed ( $g$ ) using a sensitive scale, which is read to the nearest two orders of magnitude after separating the yolk from the whites, using a plastic bottle of 0.5 liters with a diameter of $20 \mathrm{~mm}$ by applying pressure from the middle and then leaving it to separate the yolk from the whites.

\section{Results and Discussion}

\section{Shell Weight}

It during its circulation. It is evident from Table 2 that there was no significant effect of the factors of addition of tartaric and salicylic acid to the feed and water in the weight of the egg shell ( $\mathrm{g}$ ) during the first productive period, but in the second productive period it is noted that there is a high significant superiority $(\mathrm{P} \leq 0.01)$, where the $\mathrm{T} 3$ surpassed the rest of the addition factors and over $\mathrm{T} 1$, followed by the T6, T5 and T4, who outperformed T1. As for the T2 and T7, there was no significant difference between them and T1. In the third and fourth productive periods, it is noticed that all the addition transactions are superior to the control treatment, where the $\mathrm{T} 7$ exceeds in the third period, on all transactions, while the third and followed by the fifth in the fourth period surpassed the remaining addition transactions and the control treatment. As for the general average, it is noticed from the same table that there are high significant differences $(\mathrm{P} \leq 0.01)$ in the weight of the cortex between the addition factors (T2, T3, T4, T5, T6 and T7) and the control treatment (T1) during the total duration of the experiment..

Table 2. The effect of adding tartaric acid and salicylic acid to water and diet on shell weight ( $g$ ) of chicke Aged eggs

\begin{tabular}{|c|c|c|c|c|c|}
\hline \multirow{2}{*}{ treatments } & \multicolumn{4}{|c|}{ Experimental periods ( week ) } & \multirow{2}{*}{$\begin{array}{c}\text { General rate } \\
60-75\end{array}$} \\
\hline & $60-63$ & 64-67 & 68-71 & $72-75$ & \\
\hline T1 & $0.19 \pm 8.38$ & $\begin{array}{c}0.02 \pm 8.27 \\
\mathrm{c}\end{array}$ & $\begin{array}{c}0.01 \pm 8.33 \\
\mathrm{~d}\end{array}$ & $\begin{array}{c}0.05 \pm 8.04 \\
\mathrm{e}\end{array}$ & $\begin{array}{c}0.01 \pm 8.29 \\
\mathrm{~d}\end{array}$ \\
\hline $\mathbf{T 2}$ & $0.30 \pm 8.07$ & $\begin{array}{c}0.01 \pm 8.30 \\
\mathrm{c}\end{array}$ & $\begin{array}{c}0.00 \pm 9.30 \\
b\end{array}$ & $\begin{array}{c}0.01 \pm 9.11 \\
\text { bcd }\end{array}$ & $\begin{array}{c}0.02 \pm 8.70 \\
\mathrm{c}\end{array}$ \\
\hline T3 & $0.64 \pm 8.05$ & $\begin{array}{c}0.01 \pm 9.33 \\
\mathrm{a}\end{array}$ & $\begin{array}{c}0.00 \pm 9.07 \\
\mathrm{c}\end{array}$ & $\begin{array}{c}0.00 \pm 10.17 \\
\mathrm{a}\end{array}$ & $\begin{array}{c}0.00 \pm 9.15 \\
\mathrm{a}\end{array}$ \\
\hline T4 & $0.22 \pm 8.60$ & $\begin{array}{c}0.13 \pm 8.89 \\
\mathrm{~b}\end{array}$ & $\begin{array}{c}0.02 \pm 9.26 \\
b\end{array}$ & $\begin{array}{c}0.33 \pm 8.77 \\
\mathrm{~d}\end{array}$ & $\begin{array}{c}0.04 \pm 8.88 \\
\mathrm{~b}\end{array}$ \\
\hline T5 & $0.17 \pm 8.85$ & $\begin{array}{c}0.02 \pm 9.02 \\
b\end{array}$ & $\begin{array}{c}0.03 \pm 9.16 \\
\mathrm{c}\end{array}$ & $\begin{array}{c}0.00 \pm 9.64 \\
\mathrm{ab}\end{array}$ & $\begin{array}{c}0.04 \pm 9.17 \\
\mathrm{a}\end{array}$ \\
\hline T6 & $0.49 \pm 9.03$ & $\begin{array}{c}0.03 \pm 9.03 \\
b\end{array}$ & $\begin{array}{c}0.02 \pm 9.28 \\
b\end{array}$ & $\begin{array}{c}0.04 \pm 8.94 \\
\mathrm{~cd}\end{array}$ & $\begin{array}{c}0.02 \pm 9.07 \\
\mathrm{a}\end{array}$ \\
\hline T7 & $0.37 \pm 8.58$ & $\begin{array}{c}0.00 \pm 8.45 \\
\mathrm{c} \\
\end{array}$ & $\begin{array}{c}0.03 \pm 9.84 \\
\mathrm{a} \\
\end{array}$ & $\begin{array}{c}0.01 \pm 9.51 \\
\text { bc } \\
\end{array}$ & $\begin{array}{c}0.02 \pm 9.10 \\
\mathrm{a} \\
\end{array}$ \\
\hline $\begin{array}{c}\text { Significance } \\
\text { level }\end{array}$ & N.S & ** & $* *$ & $* *$ & $* *$ \\
\hline
\end{tabular}


The different letters within the same row indicate that there are significant differences between the mean of the treatments according to Tukey's test.** They indicate that there are significant effects of the treatments at the level of probability $(\mathrm{P} \leq 0.01)$ in the analysis of variance table NS There were no significant effects of the treatments in the analysis of variance table, $\mathrm{T} 1=$ control treatment $\mathrm{T} 2=$ adding $0.2 \mathrm{gm}$ tartaric acid to water, $\mathrm{T} 3=$ adding $0.2 \mathrm{gm}$ salicylic acid to water, $\mathrm{T} 4=$ adding $0.4 \mathrm{gm}$ mixture of tartaric acid and salicylic acid to water, T5 = adding $0.2 \mathrm{gm}$ of tartaric acid to the feed, T6 = adding $0.2 \mathrm{gm}$ of salicylic acid to the feed $\mathrm{T} 7=$ adding $0.4 \mathrm{~g}$ of a mixture of tartaric acid and salicylic acid to the feed.

\section{Thickness of The Shell}

This trait is considered one of the most important qualitative characteristics of the eggs produced because it controls the safety of the external appearance of the egg and the extent to which the eggs reach the consumer without being broken, it appears from Table 3 that there is no significant effect of the parameters of the addition of tartaric and salicylic acid to the diet and water in the thickness of the shell $(\mathrm{mm})$ of the aged laying hens during the period The first yield, while in the second, third and fourth production period, it is noted that there is a high significant $(\mathrm{P} \leq 0.01)$ superiority for the coefficients of addition of tartaric and salicylic acid in the thickness of the crust $(\mathrm{mm})$ compared to the control treatment.

It is evident from the same table that there is a high significant effect $(\mathrm{P} \leq 0.01)$ for the coefficients of addition of tartaric and salicylic acid in the thickness of the egg shell compared to the control during the total duration of the experiment, as the addition factors (T3, T4, T5, T6, T7) recorded a high significant improvement in thickness The eggshell compared with the control treatment, which reached the lowest values. Whereas, T2 treatment did not differ significantly with control.

Table 3. Effect of adding tartaric acid and salicylic acid to water and diet on shell thickness (mm) for chicken Aged eggs of a brown lohmann during trial durations of 75-60 weeks (mean \pm standard error)

\begin{tabular}{|c|c|c|c|c|c|}
\hline \multirow{2}{*}{ treatments } & \multicolumn{4}{|c|}{ Experimental periods ( week ) } & \multirow{2}{*}{$\begin{array}{c}\text { General rate } \\
60-75\end{array}$} \\
\hline & $60-63$ & 64-67 & 68-71 & $72-75$ & \\
\hline T1 & $0.01 \pm 0.37$ & $\begin{array}{c}0.00 \pm 0.36 \\
\mathrm{c}\end{array}$ & $\begin{array}{c}0.01 \pm 0.27 \\
\mathrm{c}\end{array}$ & $\begin{array}{c}0.01 \pm 0.32 \\
b\end{array}$ & $\begin{array}{c}0.01 \pm 0.33 \\
\mathrm{c}\end{array}$ \\
\hline $\mathbf{T} 2$ & $0.02 \pm 0.36$ & $\begin{array}{c}0.01 \pm 0.38 \\
b\end{array}$ & $\begin{array}{c}0.01 \pm 0.31 \\
b\end{array}$ & $\begin{array}{c}0.00 \pm 0.36 \\
\mathrm{a}\end{array}$ & $\begin{array}{c}0.00 \pm 0.35 \\
\text { bc }\end{array}$ \\
\hline T3 & $0.00 \pm 0.39$ & $\begin{array}{c}0.00 \pm 0.39 \\
\mathrm{ab}\end{array}$ & $\begin{array}{c}0.00 \pm 0.35 \\
\mathrm{a}\end{array}$ & $\begin{array}{c}0.00 \pm 0.38 \\
\mathrm{a}\end{array}$ & $\begin{array}{c}0.00 \pm 0.38 \\
\mathrm{a}\end{array}$ \\
\hline T4 & $0.00 \pm 0.38$ & $\begin{array}{c}0.00 \pm 0.39 \\
a b\end{array}$ & $\begin{array}{c}0.00 \pm 0.35 \\
\mathrm{a}\end{array}$ & $\begin{array}{c}0.01 \pm 0.35 \\
\mathrm{a}\end{array}$ & $\begin{array}{c}0.00 \pm 0.37 \\
\mathrm{ab}\end{array}$ \\
\hline T5 & $0.00 \pm 0.39$ & $\begin{array}{c}0.00 \pm 0.40 \\
\mathrm{a}\end{array}$ & $\begin{array}{c}0.00 \pm 0.30 \\
\mathrm{~b}\end{array}$ & $\begin{array}{c}0.01 \pm 0.37 \\
\mathrm{a}\end{array}$ & $\begin{array}{c}0.01 \pm 0.37 \\
a b\end{array}$ \\
\hline T6 & $0.00 \pm 0.39$ & $\begin{array}{c}0.00 \pm 0.39 \\
\mathrm{ab} \\
\end{array}$ & $\begin{array}{c}0.00 \pm 0.35 \\
\mathrm{a} \\
\end{array}$ & $\begin{array}{c}0.01 \pm 0.36 \\
\mathrm{a} \\
\end{array}$ & $\begin{array}{c}0.00 \pm 0.37 \\
\mathrm{ab}\end{array}$ \\
\hline T7 & $0.02 \pm 0.35$ & $\begin{array}{c}0.00 \pm 0.38 \\
\mathrm{~b}\end{array}$ & $\begin{array}{c}0.00 \pm 0.37 \\
\mathrm{a}\end{array}$ & $\begin{array}{c}0.00 \pm 0.36 \\
\mathrm{a}\end{array}$ & $\begin{array}{c}0.01 \pm 0.37 \\
a b\end{array}$ \\
\hline $\begin{array}{c}\text { Significance } \\
\text { level }\end{array}$ & N.S & $* *$ & $* *$ & $* *$ & $* *$ \\
\hline
\end{tabular}

The different letters within the same row indicate that there are significant differences between the mean of the treatments according to Tukey's test.** They indicate that there are significant effects of the treatments at the level of probability $(\mathrm{P} \leq 0.01)$ in the analysis of variance table. NS There were no significant effects of the treatments in the analysis of variance table, $\mathrm{T} 1=$ control treatment $\mathrm{T} 2=$ adding $0.2 \mathrm{gm}$ tartaric acid to water, $\mathrm{T} 3=$ adding $0.2 \mathrm{gm}$ salicylic acid to water, T4 = adding $0.4 \mathrm{gm}$ mixture of tartaric acid and salicylic acid to water, T5 = adding $0.2 \mathrm{gm}$ of tartaric acid to the feed, T6 $=$ adding $0.2 \mathrm{gm}$ of salicylic acid to the feed $\mathrm{T} 7=$ adding $0.4 \mathrm{~g}$ of a mixture of tartaric acid and salicylic acid to the feed. 


\section{Albumin High}

A higher albumin indicates better egg quality, while a lower white indicates a lower quality. Table 4 shows that there was no significant effect of the parameters of addition of tartaric and salicylic acid to the feed and water on the albumin height (mm) of the aged laying hens during the first productive period, while It is noted that there is a high significant improvement $(\mathrm{P} \leq 0.01)$ for the coefficients of addition of two acids in the height of albumin $(\mathrm{mm})$ in the rest of the second, third and fourth periods, as it is noticed that all addition factors exceed the control treatment in the second and third periods. The control treatment, with the exception of the fifth treatment, which did not differ significantly with the control treatment, and it appears from the same table that there was a high significant effect $(\mathrm{P} \leq 0.01)$ for the coefficients of addition of tartaric and salicylic acids in the albumin height $(\mathrm{mm})$ compared with the control in the general rate of the experiment, as the addition factors were recorded ( (T2, T3, T4, T5 and T7) a highly significant improvement in the albumin height $(\mathrm{mm})$, compared with the control treatment, while they did not differ together T6 was significant with the control treatment

Table 4. Effect of adding tartaric acid and salicylic acid to water and diet on albumin high (mm) for chickens Aged

\begin{tabular}{|c|c|c|c|c|c|}
\hline \multirow{2}{*}{ treatments } & \multicolumn{4}{|c|}{ Experimental periods ( week ) } & \multirow{2}{*}{$\begin{array}{c}\text { General rate } \\
60-75\end{array}$} \\
\hline & $60-63$ & 64-67 & 68-71 & $72-75$ & \\
\hline T1 & $0.24 \pm 9.35$ & $\begin{array}{c}0.23 \pm 8.62 \\
\mathrm{c}\end{array}$ & $\begin{array}{c}0.23 \pm 8.62 \\
\mathrm{~g}\end{array}$ & $\begin{array}{c}0.18 \pm 8.65 \\
\mathrm{e}\end{array}$ & $\begin{array}{c}0.17 \pm 8.65 \\
\mathrm{c}\end{array}$ \\
\hline $\mathbf{T} 2$ & $0.27 \pm 9.40$ & $\begin{array}{c}0.15 \pm 9.72 \\
\mathrm{ab}\end{array}$ & $\begin{array}{c}0.01 \pm 9.42 \\
\mathrm{e}\end{array}$ & $\begin{array}{c}0.01 \pm 9.49 \\
\mathrm{ab} \\
\end{array}$ & $\begin{array}{c}0.07 \pm 9.51 \\
\mathrm{ab} \\
\end{array}$ \\
\hline T3 & $0.34 \pm 10.39$ & $\begin{array}{c}0.09 \pm 9.08 \\
\mathrm{ab}\end{array}$ & $\begin{array}{c}0.01 \pm 9.48 \\
\mathrm{~d}\end{array}$ & $\begin{array}{c}0.01 \pm 10.00 \\
\mathrm{a}\end{array}$ & $\begin{array}{c}0.05 \pm 9.92 \\
\mathrm{a}\end{array}$ \\
\hline T4 & $0.49 \pm 9.44$ & $\begin{array}{c}0.05 \pm 10.29 \\
\mathrm{a}\end{array}$ & $\begin{array}{c}0.01 \pm 9.33 \\
\mathrm{f}\end{array}$ & $\begin{array}{c}0.00 \pm 9.62 \\
\mathrm{abc}\end{array}$ & $\begin{array}{c}0.11 \pm 9.67 \\
\mathrm{ab}\end{array}$ \\
\hline T5 & $0.44 \pm 9.05$ & $\begin{array}{c}0.10 \pm 10.04 \\
\mathrm{ab}\end{array}$ & $\begin{array}{c}0.01 \pm 9.66 \\
\mathrm{c}\end{array}$ & $\begin{array}{l}0.02 \pm 9.06 \\
\text { ed }\end{array}$ & $\begin{array}{c}0.05 \pm 9.45 \\
\mathrm{ab}\end{array}$ \\
\hline T6 & $0.11 \pm 8.66$ & $\begin{array}{c}0.19 \pm 9.46 \\
\mathrm{~b}\end{array}$ & $\begin{array}{c}0.01 \pm 9.90 \\
\mathrm{a} \\
\end{array}$ & $\begin{array}{c}0.01 \pm 9.25 \\
\text { cd } \\
\end{array}$ & $\begin{array}{c}0.10 \pm 9.32 \\
\text { bc }\end{array}$ \\
\hline T7 & $0.67 \pm 9.35$ & $\begin{array}{c}0.09 \pm 9.98 \\
\mathrm{ab}\end{array}$ & $\begin{array}{c}0.01 \pm 9.77 \\
\mathrm{~b}\end{array}$ & $\begin{array}{c}0.16 \pm 9.69 \\
a b\end{array}$ & $\begin{array}{c}0.05 \pm 9.70 \\
\mathrm{ab}\end{array}$ \\
\hline $\begin{array}{c}\text { Significance } \\
\text { level }\end{array}$ & N.S & $* *$ & $* *$ & $* *$ & $* *$ \\
\hline
\end{tabular}

The different letters within the same row indicate that there are significant differences between the mean of the treatments according to Tukey's test.** They indicate that there are significant effects of the treatments at the level of probability $(\mathrm{P} \leq 0.01)$ in the analysis of variance table NS There were no significant effects of the treatments in the analysis of variance table, $\mathrm{T} 1=$ control treatment $\mathrm{T} 2=$ adding $0.2 \mathrm{gm}$ tartaric acid to water, T3 = adding $0.2 \mathrm{gm}$ salicylic acid to water, T4 = adding $0.4 \mathrm{gm}$ mixture of tartaric acid and salicylic acid to water, T5 = adding $0.2 \mathrm{gm}$ of tartaric acid to the feed, T6 $=$ adding $0.2 \mathrm{gm}$ of salicylic acid to the feed $\mathrm{T} 7=$ adding $0.4 \mathrm{~g}$ of a mixture of tartaric acid and salicylic acid to the feed.

\section{Albumin Weight}

The albumin weight is affected by the size of the egg and also by the size of the yolk. Table 5 shows that there was no significant effect of the parameters of addition of tartaric and salicylic acid to the feed and water on the albumin weight $(\mathrm{g})$ of the of the aged laying hens during the first productive period, while a high significant effect was observed $(\mathrm{P} \leq 0.01)$. For the coefficients of adding citrus in the albumin weight $(\mathrm{g})$ in the rest of the second, third and fourth periods, as it is noticed in the second period that the $\mathrm{T} 7$ a high significant $(\mathrm{P} \leq 0.01)$, was morally superior to the control treatment and the rest of the addition treatments and did not differ materially with the T5, while the rest of the addition 
treatments did not differ significantly with T1. In the third and fourth periods, all addition transactions outperformed $\mathrm{T} 1$, and it is noticed that the T5 outperformed the remaining addition and control transactions in the two periods, except for the T3, which did not differ morally with it in the third period only. As for the general average, it is evident from the same table that a high significant effect $(\mathrm{P} \leq 0.01)$ occurred for the coefficients of addition of tartaric and salicylic acids in albumin weight ( $\mathrm{g}$ ) compared to the control, as the addition factors (T2, T3, T4, T5, T7) recorded a highly significant improvement. The weight of the albumin (gm) compared with the control treatment, While the treatment T6 did not differ significantly with the control treatment.

Table 5. Effect of adding tartaric and salicylic acid to water and diet on albumin weight ( $\mathrm{g}$ ) of chickens Aged brown Lohmann eggs during the experiment duration of 75-60 weeks (mean \pm standard error).

\begin{tabular}{|c|c|c|c|c|c|}
\hline \multirow{2}{*}{ treatments } & \multicolumn{4}{|c|}{ Experimental periods ( week ) } & \multirow{2}{*}{$\begin{array}{c}\text { General rate } \\
60-75\end{array}$} \\
\hline & $60-63$ & 64-67 & 68-71 & $72-75$ & \\
\hline T1 & $1.86 \pm 41.42$ & $\begin{array}{c}0.23 \pm 39.54 \\
c\end{array}$ & $\begin{array}{c}0.02 \pm 39.21 \\
c\end{array}$ & $\begin{array}{c}0.03 \pm 40.06 \\
\mathrm{e}\end{array}$ & $\begin{array}{c}0.19 \pm 40.06 \\
\mathrm{c}\end{array}$ \\
\hline $\mathbf{T} 2$ & $1.10 \pm 45.55$ & $\begin{array}{c}0.27 \pm 40.52 \\
\mathrm{c}\end{array}$ & $\begin{array}{c}0.23 \pm 40.99 \\
b\end{array}$ & $\begin{array}{c}0.01 \pm 41.48 \\
\mathrm{c}\end{array}$ & $\begin{array}{c}0.24 \pm 42.14 \\
b\end{array}$ \\
\hline T3 & $1.53 \pm 45.73$ & $\begin{array}{c}0.62 \pm 40.40 \\
c\end{array}$ & $\begin{array}{c}0.28 \pm 41.67 \\
\mathrm{ab}\end{array}$ & $\begin{array}{c}0.01 \pm 40.51 \\
\mathrm{~d}\end{array}$ & $\begin{array}{c}0.55 \pm 42.08 \\
b\end{array}$ \\
\hline T4 & $0.03 \pm 45.49$ & $\begin{array}{c}0.38 \pm 40.71 \\
\text { bc }\end{array}$ & $\begin{array}{c}0.34 \pm 40.87 \\
b\end{array}$ & $\begin{array}{c}0.06 \pm 40.71 \\
\mathrm{~d}\end{array}$ & $\begin{array}{c}0.19 \pm 41.95 \\
b\end{array}$ \\
\hline T5 & $0.27 \pm 43.94$ & $\begin{array}{c}0.42 \pm 42.60 \\
\mathrm{ab}\end{array}$ & $\begin{array}{c}0.03 \pm 42.59 \\
\mathrm{a}\end{array}$ & $\begin{array}{c}0.02 \pm 45.07 \\
\mathrm{a}\end{array}$ & $\begin{array}{c}0.33 \pm 43.55 \\
\mathrm{a}\end{array}$ \\
\hline T6 & $1.82 \pm 40.89$ & $\begin{array}{c}0.36 \pm 40.68 \\
\mathrm{c}\end{array}$ & $\begin{array}{c}0.11 \pm 41.51 \\
b\end{array}$ & $\begin{array}{c}0.04 \pm 42.35 \\
\mathrm{~b}\end{array}$ & $\begin{array}{c}0.17 \pm 41.36 \\
\text { bc }\end{array}$ \\
\hline $\mathbf{T 7}$ & $1.48 \pm 44.19$ & $\begin{array}{c}0.37 \pm 42.36 \\
\mathrm{a}\end{array}$ & $\begin{array}{c}0.08 \pm 41.39 \\
b\end{array}$ & $\begin{array}{c}0.20 \pm 41.69 \\
\text { c }\end{array}$ & $\begin{array}{c}0.38 \pm 42.48 \\
\mathrm{ab}\end{array}$ \\
\hline $\begin{array}{c}\text { Significance } \\
\text { level }\end{array}$ & N.S & $* *$ & $* *$ & $* *$ & $* *$ \\
\hline
\end{tabular}

The different letters within the same row indicate that there are significant differences between the mean of the treatments according to Tukey's test.** They indicate that there are significant effects of the treatments at the level of probability $(\mathrm{P} \leq 0.01)$ in the analysis of variance table NS There were no significant effects of the treatments in the analysis of variance table, $\mathrm{T} 1=$ control treatment $\mathrm{T} 2=$ adding $0.2 \mathrm{gm}$ tartaric acid to water, T3 = adding $0.2 \mathrm{gm}$ salicylic acid to water, T4 = adding $0.4 \mathrm{gm}$ mixture of tartaric acid and salicylic acid to water, T5 = adding $0.2 \mathrm{gm}$ of tartaric acid to the feed, T6 $=$ adding $0.2 \mathrm{gm}$ of salicylic acid to the feed $\mathrm{T} 7=$ adding $0.4 \mathrm{~g}$ of a mixture of tartaric acid and salicylic acid to the feed.

\section{Haugh unit}

It is evident from Table 6 that there was no significant effect for the parameters of adding tartaric and salicylic acid to feed and water in unit haugh for old layer chickens during the first productive period, while it is noted that there is a significant effect in favor of the factors of addition of two acids in a haugh unit in the second, third and fourth production period compared with the control treatment. Where I give the coefficients (T3, T4, T6, T7) the best values. It is noted from the same table that there is a highly significant effect $(\mathrm{P} \leq 0.01)$ of the treatments of adding tartaric and salicylic acids in unit haugh compared with the control in the general average of the experiment, as it was recorded Addition coefficients (T2, T3, T4, T7) were a highly significant improvement in haugh unit, compared with the control treatment, while the two addition factors T5 and T6 did not differ significantly with treatment the control. 
Table 6. The effect of adding tartaric acid and salicylic acid to water and diet in unit haugh forAged hens Lohmann brown during trial durations of 75-60 weeks (mean \pm standard error)

\begin{tabular}{|c|c|c|c|c|c|}
\hline \multirow{2}{*}{ treatments } & \multicolumn{4}{|c|}{ Experimental periods ( week ) } & $\begin{array}{c}\text { General rate } \\
\mathbf{6 0 - 7 5}\end{array}$ \\
\cline { 2 - 6 } & $\mathbf{6 0 - 6 3}$ & $\mathbf{6 4 - 6 7}$ & $\mathbf{6 8 - 7 1}$ & $\mathbf{7 2 - 7 5}$ & $0.12 \pm 92.91$ \\
$\mathrm{~T} 1$ & $1.03 \pm 95.19$ & $\begin{array}{c}1.23 \pm 91.60 \\
\mathrm{c}\end{array}$ & $\begin{array}{c}0.08 \pm 92.90 \\
\mathrm{~d}\end{array}$ & $\begin{array}{c}0.81 \pm 91.94 \\
\mathrm{~d}\end{array}$ & $\begin{array}{c}0.94 \\
\mathrm{c}\end{array}$ \\
\hline T2 & $1.48 \pm 94.35$ & $\begin{array}{c}0.82 \pm 96.90 \\
\mathrm{ab}\end{array}$ & $\begin{array}{c}0.19 \pm 95.10 \\
\mathrm{c}\end{array}$ & $\begin{array}{c}0.72 \pm 94.44 \\
\mathrm{ab}\end{array}$ & $\begin{array}{c}0.54 \pm 95.45 \\
\mathrm{ab}\end{array}$ \\
\hline T3 & $1.42 \pm 99.15$ & $\begin{array}{c}0.60 \pm 97.22 \\
\mathrm{ab}\end{array}$ & $\begin{array}{c}0.20 \pm 95.53 \\
\mathrm{bc}\end{array}$ & $\begin{array}{c}0.50 \pm 97.93 \\
\mathrm{a}\end{array}$ & $\begin{array}{c}0.37 \pm 97.46 \\
\mathrm{a}\end{array}$ \\
\hline T4 & $2.54 \pm 94.44$ & $\begin{array}{c}0.43 \pm 99.35 \\
\mathrm{a}\end{array}$ & $\begin{array}{c}0.13 \pm 94.85 \\
\mathrm{c}\end{array}$ & $\begin{array}{c}0.25 \pm 96.37 \\
\mathrm{ab}\end{array}$ & $\begin{array}{c}0.41 \pm 96.25 \\
\mathrm{ab}\end{array}$ \\
\hline T5 & $2.25 \pm 92.48$ & $\begin{array}{c}0.36 \pm 97.85 \\
\mathrm{ab}\end{array}$ & $\begin{array}{c}0.18 \pm 96.03 \\
\mathrm{~b}\end{array}$ & $\begin{array}{c}0.04 \pm 92.34 \\
\mathrm{c}\end{array}$ & $\begin{array}{c}0.53 \pm 94.68 \\
\mathrm{bc}\end{array}$ \\
\hline T6 & $0.53 \pm 91.19$ & $\begin{array}{c}0.77 \pm 95.34 \\
\mathrm{~b}\end{array}$ & $\begin{array}{c}0.19 \pm 97.41 \\
\mathrm{a}\end{array}$ & $\begin{array}{c}0.60 \pm 93.96 \\
\mathrm{bc}\end{array}$ & $\begin{array}{c}0.54 \pm 94.48 \\
\mathrm{bc}\end{array}$ \\
\hline T7 & $3.81 \pm 94.14$ & $\begin{array}{c}0.41 \pm 97.64 \\
\mathrm{ab}\end{array}$ & $\begin{array}{c}0.15 \pm 96.91 \\
\mathrm{a}\end{array}$ & $\begin{array}{c}0.75 \pm 96.19 \\
\mathrm{ab}\end{array}$ & $\begin{array}{c}0.75 \pm 96.22 \\
\mathrm{ab}\end{array}$ \\
\hline $\begin{array}{c}\text { Significance } \\
\text { level }\end{array}$ & $\mathbf{N . S}$ & $* *$ & $*$ & $* *$ & $* *$ \\
\hline
\end{tabular}

The different letters within the same row indicate that there are significant differences between the means of the coefficients according to the Tukey test. * Indicates the presence of significant effects of the treatments at the probability level $(\mathrm{P} \leq 0.05)$ in the analysis of variance table, ** Indicates the presence of significant effects of the treatments at the probability level $(\mathrm{P} \leq 0.01)$ in the analysis of variance table. NS There were no significant effects of the treatments in the analysis of variance table, $\mathrm{T} 1=$ control treatment $\mathrm{T} 2=$ adding $0.2 \mathrm{gm}$ tartaric acid to water, T3 = adding $0.2 \mathrm{gm}$ salicylic acid to water, $\mathrm{T} 4=$ adding $0.4 \mathrm{gm}$ mixture of tartaric acid and salicylic acid to water, T5 = adding $0.2 \mathrm{gm}$ of tartaric acid to the feed, T6 $=$ adding $0.2 \mathrm{gm}$ of salicylic acid to the feed $\mathrm{T} 7=$ adding $0.4 \mathrm{~g}$ of a mixture of tartaric acid and salicylic acid to the feed.

\section{Yolk height}

It is one of the measures that expresses the quality of the yolk and through it the yolk index can be known. It is clear from Table 7 that there is no significant effect of the treatments of adding tartaric and salicylic acids to feed and water on the yolk Height of aged laying hens during the first productive period, while it is noted that there is a significant effect in favor of the treatments The addition of the two acids (T2, T3, T4, T5, T6 and T7) in the yolk Height in the rest of the production period (second, third and fourth) compared with the control treatment, where the treatment $\mathrm{T} 2$ gave the best values. With regard to the general average of the experiment, it appears from the same table that there is a highly significant effect $(P \leq 0.01)$ of the addition treatments of tartaric and salicylic acids on the yolk Height compared with control The addition coefficients (T2, T3, T4) recorded a highly significant improvement in the yolk height, compared with the control treatment, while the addition coefficients T5, T6 and T7 did not differ significantly with the control treatment. 
Diyala Agricultural Sciences Journal Vol (13) No.2 , 2021: 32-51

Table 7. Effect of adding tartaric and salicylic acid to water and diet on yolk height (mm) for Chickens. Aged brown

\begin{tabular}{|c|c|c|c|c|c|}
\hline \multirow{2}{*}{ treatments } & \multicolumn{4}{|c|}{ Experimental periods ( week ) } & \multirow{2}{*}{$\begin{array}{c}\text { General } \\
\text { rate } \\
60-75\end{array}$} \\
\hline & $60-63$ & 64-67 & 68-71 & $72-75$ & \\
\hline T1 & $0.34 \pm 20.09$ & $\begin{array}{c}0.01 \pm 18.34 \\
\mathrm{c}\end{array}$ & $\begin{array}{c}0.01 \pm 18.18 \\
\mathrm{e}\end{array}$ & $\begin{array}{c}0.03 \pm 17.94 \\
\text { c }\end{array}$ & $\begin{array}{c}0.49 \pm 18.64 \\
\text { c }\end{array}$ \\
\hline $\mathbf{T} 2$ & $0.23 \pm 20.87$ & $\begin{array}{c}0.13 \pm 19.75 \\
\mathrm{a} \\
\end{array}$ & $\begin{array}{c}0.02 \pm 19.97 \\
\mathrm{a} \\
\end{array}$ & $\begin{array}{c}0.08 \pm 19.89 \\
\mathrm{a}\end{array}$ & $\begin{array}{c}0.25 \pm 20.12 \\
\mathrm{a} \\
\end{array}$ \\
\hline T3 & $0.21 \pm 20.55$ & $\begin{array}{c}0.14 \pm 19.72 \\
a\end{array}$ & $\begin{array}{c}0.05 \pm 19.61 \\
b\end{array}$ & $\begin{array}{c}0.21 \pm 19.32 \\
\mathrm{ab}\end{array}$ & $\begin{array}{c}0.21 \pm 19.94 \\
\mathrm{ab}\end{array}$ \\
\hline $\mathbf{T 4}$ & $0.23 \pm 19.79$ & $\begin{array}{c}0.13 \pm 19.75 \\
a\end{array}$ & $\begin{array}{c}0.01 \pm 19.28 \\
\mathrm{c}\end{array}$ & $\begin{array}{c}0.30 \pm 19.23 \\
\mathrm{ab}\end{array}$ & $\begin{array}{c}0.1519 .51 \\
\mathrm{ab}\end{array}$ \\
\hline T5 & $0.30 \pm 19.81$ & $\begin{array}{c}0.01 \pm 19.17 \\
b\end{array}$ & $\begin{array}{c}0.05 \pm 18.95 \\
\mathrm{~d}\end{array}$ & $\begin{array}{c}0.07 \pm 19.05 \\
b\end{array}$ & $\begin{array}{c}0.19 \pm 19.25 \\
\text { bc }\end{array}$ \\
\hline T6 & $0.08 \pm 19.74$ & $\begin{array}{c}0.04 \pm 19.76 \\
\mathrm{a}\end{array}$ & $\begin{array}{c}0.08 \pm 18.84 \\
\mathrm{~d}\end{array}$ & $\begin{array}{c}0.04 \pm 19.02 \\
b\end{array}$ & $\begin{array}{c}0.24 \pm 19.34 \\
\text { bc }\end{array}$ \\
\hline T7 & $0.29 \pm 19.88$ & $\begin{array}{c}0.01 \pm 19.21 \\
\mathrm{~b}\end{array}$ & $\begin{array}{c}0.01 \pm 18.76 \\
\mathrm{~d}\end{array}$ & $\begin{array}{c}0.13 \pm 19.23 \\
\mathrm{ab}\end{array}$ & $\begin{array}{c}0.23 \pm 19.27 \\
\text { bc }\end{array}$ \\
\hline $\begin{array}{c}\text { Significance } \\
\text { level }\end{array}$ & N.S & $* *$ & $* *$ & $* *$ & $* *$ \\
\hline
\end{tabular}

The different letters within the same row indicate that there are significant differences between the mean of the treatments according to Tukey's test. ** They indicate that there are significant effects of the treatments at the level of probability $(\mathrm{P} \leq 0.01)$ in the analysis of variance table. NS There were no significant effects of the treatments in the analysis of variance table, T1 = control treatment $\mathrm{T} 2=$ adding $0.2 \mathrm{gm}$ tartaric acid to water, T3 = adding $0.2 \mathrm{gm}$ salicylic acid to water, $\mathrm{T} 4$ = adding $0.4 \mathrm{gm}$ mixture of tartaric acid and salicylic acid to water, T5 = adding $0.2 \mathrm{gm}$ of tartaric acid to the feed, T6 = adding $0.2 \mathrm{gm}$ of salicylic acid to the feed $\mathrm{T} 7=$ adding $0.4 \mathrm{~g}$ of $\mathrm{a}$ mixture of tartaric acid and salicylic acid to the feed.

\section{Yolk diameter}

This trait gives an idea of the quality of the yolk and the egg in general, and through it the yolk index can be known. It appears from Table 8 that there was no significant effect of the factors of addition of tartaric and salicylic acid to the feed and water in the yolk diameter of the aged layer hens during the first productive period, while there was a high significant effect $(\mathrm{P} \leq 0.01)$ in favor of the two acids addition factors (T3, T4, T6 and T7) in The diameter of the yolk in the second productive period compared with the control, while the two addition coefficients (T2 and T5) did not differ significantly with the control treatment. As for the third productive period, we notice a highly significant superiority of all addition treatments compared to the control treatment, while in the fourth productive period, we notice a highly significant superiority of the addition treatments (T2, T3 and T4) compared to the control treatment. While the addition treatments (T5, T6 and T7) did not make any significant difference from the control treatment. It is noted from the same table that there is a highly significant effect $(\mathrm{P} \leq 0.01)$ of the addition treatments of tartaric and salicylic acids in the yolk diameter compared with the control during the whole period of the experiment, as all the addition treatments (T2, T3, T4, T5, T6 and T7) recorded a highly significant improvement in the diameter of the yolk. Compared with the control treatment. 
Diyala Agricultural Sciences Journal Vol (13) No.2 , 2021: 32-51

Table 8. Effect of adding tartaric and salicylic acid to water and diet on yolk diameter (mm) for chickens aged brown Lohmann eggs during the experiment duration of 75-60

Weeks (mean \pm standard error)

\begin{tabular}{|c|c|c|c|c|c|}
\hline \multirow{2}{*}{ treatments } & \multicolumn{4}{|c|}{ Experimental periods ( week ) } & \multirow{2}{*}{$\begin{array}{c}\text { General } \\
\text { rate } \\
60-75\end{array}$} \\
\hline & $60-63$ & 64-67 & $68-71$ & $72-75$ & \\
\hline T1 & $0.12 \pm 40.46$ & $\begin{array}{c}0.37 \pm 41.95 \\
b\end{array}$ & $\begin{array}{c}0.33 \pm 41.82 \\
b\end{array}$ & $\begin{array}{c}0.31 \pm 42.65 \\
\mathrm{c} \\
\end{array}$ & $\begin{array}{c}0.11 \pm 41.72 \\
\mathrm{c}\end{array}$ \\
\hline $\mathbf{T} 2$ & $0.26 \pm 41.08$ & $\begin{array}{c}0.20 \pm 40.64 \\
\mathrm{ab}\end{array}$ & $\begin{array}{c}0.01 \pm 39.34 \\
\mathrm{a}\end{array}$ & $\begin{array}{c}0.33 \pm 39.85 \\
\mathrm{ab}\end{array}$ & $\begin{array}{c}0.17 \pm 40.23 \\
\mathrm{ab}\end{array}$ \\
\hline T3 & $0.29 \pm 39.44$ & $\begin{array}{c}0.30 \pm 39.50 \\
\mathrm{a}\end{array}$ & $\begin{array}{c}0.01 \pm 39.15 \\
\mathrm{a}\end{array}$ & $\begin{array}{c}0.31 \pm 38.79 \\
\mathrm{a}\end{array}$ & $\begin{array}{c}0.16 \pm 39.22 \\
\mathrm{a}\end{array}$ \\
\hline T4 & $0.19 \pm 40.10$ & $\begin{array}{c}0.23 \pm 39.62 \\
\mathrm{a} \\
\end{array}$ & $\begin{array}{c}0.33 \pm 38.88 \\
\mathrm{a} \\
\end{array}$ & $\begin{array}{c}0.59 \pm 39.80 \\
\mathrm{ab}\end{array}$ & $\begin{array}{c}0.26 \pm 39.60 \\
\mathrm{ab}\end{array}$ \\
\hline T5 & $0.60 \pm 41.34$ & $\begin{array}{c}0.67 \pm 40.31 \\
\mathrm{ab}\end{array}$ & $\begin{array}{c}0.34 \pm 39.62 \\
\mathrm{a}\end{array}$ & $\begin{array}{c}0.24 \pm 40.97 \\
\text { bc }\end{array}$ & $\begin{array}{c}0.38 \pm 40.56 \\
b\end{array}$ \\
\hline T6 & $1.26 \pm 40.03$ & $\begin{array}{c}0.21 \pm 39.80 \\
\mathrm{a} \\
\end{array}$ & $\begin{array}{c}0.18 \pm 39.65 \\
\mathrm{a}\end{array}$ & $\begin{array}{c}0.07 \pm 41.06 \\
\text { bc }\end{array}$ & $\begin{array}{c}0.18 \pm 40.14 \\
\mathrm{ab}\end{array}$ \\
\hline T7 & $0.45 \pm 40.08$ & $\begin{array}{c}0.31 \pm 39.71 \\
\mathrm{a}\end{array}$ & $\begin{array}{c}0.59 \pm 38.63 \\
a\end{array}$ & $\begin{array}{c}0.46 \pm 41.14 \\
\text { bc }\end{array}$ & $\begin{array}{c}0.13 \pm 39.89 \\
\mathrm{ab}\end{array}$ \\
\hline $\begin{array}{c}\text { Significance } \\
\text { level }\end{array}$ & N.S & $* *$ & $* *$ & $* *$ & $* *$ \\
\hline
\end{tabular}

The different letters within the same row indicate that there are significant differences between the mean of the treatments according to Tukey's test. ** They indicate that there are significant effects of the treatments at the level of probability $(\mathrm{P} \leq 0.01)$ in the analysis of variance table. NS There were no significant effects of the treatments in the analysis of variance table, $\mathrm{T} 1=$ control treatment $\mathrm{T} 2=$ adding $0.2 \mathrm{gm}$ tartaric acid to water, T3 = adding 0.2 gm salicylic acid to water, $\mathrm{T} 4$ = adding $0.4 \mathrm{gm}$ mixture of tartaric acid and salicylic acid to water, T5 = adding $0.2 \mathrm{gm}$ of tartaric acid to the feed, T6 = adding $0.2 \mathrm{gm}$ of salicylic acid to the feed $\mathrm{T} 7=$ adding $0.4 \mathrm{~g}$ of $\mathrm{a}$ mixture of tartaric acid and salicylic acid to the feed.

\section{Yolk weight}

The results of Table 9 show that there was no significant effect of the factors of addition of tartaric and salicylic acid to the feed and water on the yolk weight of the old laying hens during the first production period, As for the second productive period, there was a significant effect of the addition treatment T6 compared to the control treatment, while the treatment T6 did not differ significantly from the rest of the addition treatments, which in turn did not differ significantly from the control treatment, and it is noted that in the third productive period, all the addition treatments in the weight of the yolk outperformed the control treatment. Where the second treatment gave the best values, while the seventh treatment did not record any significant difference compared with the control treatment As for the fourth production period, all the treatments of adding the two acids were superior to the weight of the yolk compared to the control, where the treatments T2, T6, and T7 gave the best values. It is noted from the same table that there is a highly significant effect $(\mathrm{P} \leq 0.01)$ of the addition treatments of tartaric and salicylic acids on the weight of the yolk compared with the control in the overall average of the experiment, The addition treatments (T2, T5, T6, T7) recorded a highly significant improvement in yolk weight compared with the control treatment, while there was no significant effect for the addition treatments ( T3, T4) in yolk weight compared with control. 
Diyala Agricultural Sciences Journal Vol (13) No.2 , 2021: 32-51

Table 9. Effect of adding tartaric acid and salicylic acid to water and diet on yolk weight $(\mathrm{g})$ for chicken aged brown Lohmann eggs during the experiment duration of 75-60 Weeks (mean \pm standard error)

\begin{tabular}{|c|c|c|c|c|c|}
\hline \multirow{2}{*}{ treatments } & \multicolumn{4}{|c|}{ Experimental periods ( week ) } & \multirow{2}{*}{$\begin{array}{c}\text { General rate } \\
60-75\end{array}$} \\
\hline & $60-63$ & 64-67 & 68-71 & $72-75$ & \\
\hline T1 & $0.83 \pm 15.57$ & $\begin{array}{c}0.23 \pm 15.04 \\
b\end{array}$ & $\begin{array}{c}0.02 \pm 15.03 \\
\mathrm{e}\end{array}$ & $\begin{array}{c}0.33 \pm 14.83 \\
\mathrm{~d}\end{array}$ & $\begin{array}{c}0.16 \pm 15.12 \\
\mathrm{c}\end{array}$ \\
\hline $\mathbf{T 2}$ & $0.53 \pm 16.60$ & $\begin{array}{c}0.15 \pm 16.30 \\
a b\end{array}$ & $\begin{array}{c}0.02 \pm 16.72 \\
\mathrm{a}\end{array}$ & $\begin{array}{c}0.01 \pm 16.74 \\
\mathrm{a}\end{array}$ & $\begin{array}{c}0.10 \pm 16.59 \\
a b\end{array}$ \\
\hline $\mathbf{T 3}$ & $0.58 \pm 15.26$ & $\begin{array}{c}0.14 \pm 15.88 \\
a b\end{array}$ & $\begin{array}{c}0.04 \pm 15.61 \\
\mathrm{~d}\end{array}$ & $\begin{array}{c}0.02 \pm 15.87 \\
\mathrm{c}\end{array}$ & $\begin{array}{c}0.15 \pm 15.66 \\
b c\end{array}$ \\
\hline T4 & $0.53 \pm 15.85$ & $\begin{array}{c}0.40 \pm 16.25 \\
a b\end{array}$ & $\begin{array}{c}0.02 \pm 16.05 \\
\mathrm{c}\end{array}$ & $\begin{array}{c}0.04 \pm 16.04 \\
\text { bc }\end{array}$ & $\begin{array}{c}0.08 \pm 16.05 \\
\text { abc }\end{array}$ \\
\hline T5 & $0.47 \pm 17.11$ & $\begin{array}{c}0.31 \pm 16.23 \\
a b\end{array}$ & $\begin{array}{c}0.01 \pm 16.26 \\
b\end{array}$ & $\begin{array}{c}0.02 \pm 16.60 \\
a b\end{array}$ & $\begin{array}{c}0.20 \pm 16.55 \\
\mathrm{ab}\end{array}$ \\
\hline T6 & $0.44 \pm 17.38$ & $\begin{array}{c}0.42 \pm 16.94 \\
\mathrm{a} \\
\end{array}$ & $\begin{array}{c}0.04 \pm 15.96 \\
\mathrm{c}\end{array}$ & $\begin{array}{c}0.02 \pm 17.09 \\
\mathrm{a}\end{array}$ & $\begin{array}{c}0.31 \pm 16.84 \\
\mathrm{a}\end{array}$ \\
\hline $\mathbf{T 7}$ & $0.41 \pm 16.74$ & $\begin{array}{c}0.14 \pm 16.38 \\
a b\end{array}$ & $\begin{array}{c}0.02 \pm 15.12 \\
\mathrm{e}\end{array}$ & $\begin{array}{c}0.02 \pm 16.67 \\
\mathrm{a}\end{array}$ & $\begin{array}{c}0.38 \pm 16.23 \\
a b\end{array}$ \\
\hline $\begin{array}{c}\text { Significance } \\
\text { level }\end{array}$ & N.S & * & $* *$ & $* *$ & $* *$ \\
\hline
\end{tabular}

The different letters within the same row indicate that there are significant differences between the means of the coefficients according to the Tukey test. * Indicates the presence of significant effects of the treatments at the probability level $(\mathrm{P} \leq 0.05)$ in the analysis of variance table, $* *$ Indicates the presence of significant effects of the treatments at the probability level $(\mathrm{P} \leq 0.01)$ in the analysis of variance table. NS There were no significant effects of the treatments in the analysis of variance table, $\mathrm{T} 1=$ control treatment $\mathrm{T} 2=$ adding $0.2 \mathrm{gm}$ tartaric acid to water, $\mathrm{T} 3=$ adding $0.2 \mathrm{gm}$ salicylic acid to water, T4 = adding $0.4 \mathrm{gm}$ mixture of tartaric acid and salicylic acid to water, T5 = adding $0.2 \mathrm{gm}$ of tartaric acid to the feed, T6 = adding $0.2 \mathrm{gm}$ of salicylic acid to the feed $\mathrm{T} 7=$ adding $0.4 \mathrm{~g}$ of a mixture of tartaric acid and salicylic acid to the feed.

From the results of the qualitative characteristics of eggs it is noticed that the addition of organic acids (tartaric and salicylic) in the feeding of laying hens, whether separately or in a mixture, had a significant effect in improving them, and that this improvement in egg quality characteristics may be attributed to the role of organic acids (tartaric and salicylic) used. In feeding birds, it reduces the $\mathrm{pH}$ of the intestines, increases the number of lactic acid bacteria, and reduces the number of coliform bacteria in the intestines. The improvement of the intestinal flora of domestic birds and the internal environment of the intestine results in the improvement and maintenance of the tissue properties of the intestine, the production of a number of digestive enzymes and vitamins, the improvement of the digestion and absorption process, and the readiness of nutrients, especially calcium and phosphorous (Swiatkiewicz et al., 2010; Bansod et al., 2020; Aristimunha, 2020). Or may be due to the role of organic acids as an antioxidant and a source of energy, as it works to reduce the formation of free radicals that damage cells of the body, including villous cells, which also have a ready source of energy (Santana et al., 2019; Bansod et al., 2020), and the addition of organic acids In nutrition, it increases the ability of the intestine to digest and absorb nutrients, and improves the health of the intestinal villi (Krauze et al., 2021). Or, the reason may be due to the role of organic acids in lowering the $\mathrm{pH}$ inside the bird's digestive system. It is known that harmful microbes are not suitable for an acidic environment and tend more to live in alkaline environments, thus eliminating them or reducing their activity and reproduction, and on the contrary, beneficial bacteria and microflora thrive more in Acidic media causes them to grow, multiply and compete with harmful bacteria and microbes (Wu et al., 2018; Nguyen and Kim, 2020). In addition, some organic 
acids (tartaric and malic acid) have a direct effect that kills or inhibits harmful bacteria such as Salmonella spp., Escherichia coli and clostridia, as these acids have the ability to break down the bacterial cell wall and affect their reproduction process (Dhawale ( 2005). This may be due to the fact that aged chickens at the end of the production stages are exposed to weak ability of their intestinal system, and this limits the efficiency of absorption of nutrients. It increases the solubility of mineral elements, especially calcium and phosphorous, fermentation of indigestible sugars, inhibiting the competition of harmful intestinal bacteria and preventing their competition from the host on the available nutrients and the possibility of reducing bacterial toxicity, Like ammonia and amines (Tang et al., 2017; Hassan et al., 2019; Peng et al., 2020), these organic acids are a ready-made energy source for cellular cells, improving the perpetuation of the histological properties of the intestine (Mahdavi et al., 2019; Doneria et al., 2020), which will be reflected in the improvement of digestion and absorption processes, and thus the quality of the eggs produced.

\section{Conclusion}

We conclude from the study that the addition of tartaric and salicylic acids to water and feed individually and in a mixture in feeding old laying hens during the last period of their productive life has an important role in improving the ability of the intestine to digest and absorb by increasing the surface area of the intestine and increasing the number of bacteria of the intestinal flora and thus reaching the maximum benefit for domestic birds, and as a result led to an improvement in the quality of the eggs produced. The antibacterial activity occurs due to the degradability of the organic acid, The organic acid molecule, when it is not degraded, can easily penetrate the gram-negative bacterial cell wall into the bacteria and after it reaches the cytoplasm of the bacterial cell, it will degrade into a positively charged proton and a negatively charged ion, As for the positively charged proton, its accumulation inside the bacterial cell in a large amount will lead to an increase in acidity to a degree that the bacterial cell cannot tolerate, which will push the bacterial cell to spend most of its energy for the purpose of adjusting the $\mathrm{pH}$ inside it, and this will lead to the depletion of the cell's energy and death or the inhibition of its growth and reproduction to a degree big, As for the accumulation of the negatively charged ionic slit, it will lead to a disturbance in the process of replication of DNA, which leads to the inability of bacteria to reproduce, and this accumulation also leads to a disturbance in the level of osmotic pressure inside the bacterial cell and thus will lead to its death or explosion (Vinus and Tewatia, 2017.(

\section{Conflict of Interests}

There is no conflict of interest between authors.

\section{Acknowledgments}

The authors thank the college of agriculture University of Diyala for their assistance in conducting the research, as well as workers in the poultry field of the Department of Animal production-College of Agriculture-University of Diyala.

\section{References}

Abdelli, N., J. F. Pérez, E. Vilarrasa., I. C. Luna., D. Melo-Duran., M. D.Angelo and D. Solà-Oriol. 2020. Targeted-Release Organic Acids and Essential Oils Improve Performance and Digestive Function in Broilers under a Necrotic Enteritis Challenge. Animals, 10(2): 259-266.

Alfayadh, Hamdi Abdel Aziz and Saad Abdul Hussein Naji. 1989. Poultry Product Technology. First edition. Directorate of Higher Education Printing Press. Baghdad, Iraq.

Al-Gharawi, J. K., A. H. Al-Helali and I. F. AlZamili. 2018. Effect of using different ways to provide the iraq probitic on some productive traits of broiler. Plant Archives, 18(1): 1102-1108.

Al-Khalaifah, H. S. 2018. Benefits of probiotics and/or prebiotics for antibiotic-reduced poultry. Poultry Science, 97(11): 3807-3815.

Aristimunha, P. C.; R. D. Mallheiros; P. R. Ferket; K. M. Cardinal; F. A. Moreira; E. T. Santos and A.M. Ribeiro. 2020. Effect of dietary organic acids and hemic substance supplementation on performance; immune response and gut morphology of broiler chickens. J. Appl. Poult. Res., 29(1): 85-94.

Attia, F. A., H. S. A. EL-Haliem., I. H. Hermes and M. M. Mahmoud. 2018. Effect of organic acid supplementation on nutrients digestibility, gut microbiota and immune response of broiler chicks. Egyptian Poultry Science Journal, 38(1):223-239 .

Bansod, A. P., A. G. Kolaskar., D. J. Abhilash., R. J. Pratik., S. R. urjagade and S. J. Morkhade. 2020. 
Review on recent advances in uses of organic acids in poultry production. International Journal of Veterinary Sciences and Animal Husbandry, 5(4): 26-30.

Dhawale, A. 2005. Better eggshell quality with a gut acidifier. Poultry International, 44: 18-21.

Doneria, R.; M. Dubey; M. K. Gendley; R. C. Ramteke and R. Pathak. 2020. Essential oils and Organic Acids: Feed Additive in Broiler Chickens. Int. J. Curr. Microbiol.App. Sci., 9(6): 3586-3593.

fayadh, Hamdi Abdel Aziz, Saad Abdel Hussein Naji and Nadia Nayef Abdel Hajo. 2010. Poultry Products Technology, Part 1. Egg and egg production technology. Ministry of Higher Education and Scientific Research. The Republic of Iraq.

Hassan, M. A and A.T.D Al- Timimi. 2017. Effect of adding lactic and acetic acid to the diet in prod performance of layining hens. Diyala Agriculture Sciences Journal, 9 (special issue): 25-36.

Hassan, M. Hassan, M. R., S. Sultana., M. O. Al Rahman., M. A. G. Rabbani., N. R. Sarker., Y. C. Ju and K. S. Ryu. 2019. Effect of feeding various probiotics on performance, blood properties, egg quality, and yolk fatty acid composition of laying hens. Australian Journal of Science and Technology, 3(1): 43-47.

Iba, A. M. and A. B.Jr. 1995.Studies on the use of aformic acid-propionic acid mixture (Bio-addTM) to control experimental Salmonella infection in broiler chickens. Avian Pathology, 24(2):303-311.

Jasim, M. S and A.Y. Taha. 2017. Use of supplementation of probiotic with different levels of citric acid as prometer for productive performance of laying hens. Diyala Agriculture Sciences Journal, 9 (special issue): 1-15.

Kaya H., A. Kaya., M. Gül., S. Çelebi., S. Timurkaan and B. Apaydin. 2014. Effects of supplementation of different levels of organic acids mixture to the diet on performance, egg quality parameters, serum traits and histological criteria of laying hens. Europ Poultry Science, 78: 1-12.

Krauze, M., M., Cendrowska-Pinkosz, P., Matuseviĉius, A., Stępniow ska, P., Jurczak and K. Ognik. 2021. The Effect of Administration of a Phytobiotic Containing Cinnamon Oil and Citric Acid on the Metabolism, Immunity, and Growth
Performance of Broiler Chick ens. Animals, 11(2): 399-417.

Liu, T., C. Li., Y. Li and F. Feng. 2020. Glycerol Monolaurate Enhances Reproductive Performance, Egg Quality and Albumen Amino Acids Composition in Aged Hens with Gut Microbiota Alternation. Agriculture, 10(7): 250-258.

Mahdavi, A. H., H. R. Rahmani and J. Pourreza. 2019. Probiotic inclusion in in dierent levels of barley substitution for corn diets on laying hen's histological changes of duodenum. In Proceedings of the European Symposium on Poultry Nutrition, Gdansk, Poland, 14(8): 10-13.

Neveling, D. P. 2018. Safety of antibiotic and probiotic feed additives for Gallus gallus domesticus.Thesis (PhD)-Stellenbosch University.

Nguyen, D. H. and I. H. Kim. 2020. Protected Organic Acids Improved Growth Performance, Nutrient Digestibility, and Decreased Gas Emission in Broilers. Anim., 10(3): 1-11.

NRC. 1994. Nutrient requirements of poultry. (9th rev. ed.). National Research Council. National Academy Press, Washington, DC, USA Peng, M., Z. Tabashsum, M. Anderson, A. Truong, A. K. Houser, J. Padill and D. Biswas. 2020. Effectiveness of probiotics, prebiotics, and prebiotic-like components in common functional foods. Comprehensive Reviews in Food Science and Food Safety, (19): 1908-1933.

Qu, X. Y., J. F., Chen, C. Q., He, F., Chi and S. L. Johnston. 2018. Effects of modified montmorillonite adsorbent on performance, egg quality, serum biochemistry, oxidation status, and immune response of laying hens in late production. Livestock Science, 210: 15-20.

Santana, T. P., J. A. Jesus, M. S. Bastos, A. S. Nunes, G. O. Júnior, C. S. Nascimento and A. P. Del. 2019. Antioxidant activity and duodenum transporter gene expression in quail fed citric acid. South. Afr. J. Anim. Sci. 49(4): 636-643.

SAS Institute. 2001. SAS User's Guide: Statistics Version 6.12ed. SAS Inst. Inc., Cary, NC., USA.

Swiatkiewicz, S., J. Koreleski and A.Arczewska. 2010. Laying performance and eggshell quality in laying hens fed diets supplemented with prebiotics and organic acids. Czech J. Ahim. Sci., 55(7): 244306. 
Tang, S. G. H., C. C. Sieo., K. Ramasamy., W. Z. Saad., H. K. Wong and Y. W. Ho. 2017. Performance, biochemical and haematological responses, and relative organ weights of laying hens fed diets supplemented with prebiotic, probiotic and synbiotic. BMC Veterinary Research, 13(1): 248256.

The Chemical Company. 2010. Tartaric Acid Overview.

Vinus, N. S. and B. S. Tewatia. 2017. Organic acids as alternatives to anti biotic growth parmeters in poultry. Pharma. Inno. J., 6(11):164-169.

Wu, W., Z. Xiao., W. An., Y. Dong and B. Zhang. 2018. Dietary sodium butyrate improves intestinal development and function by modulating the microbial community in broilers. PloS one.,13(5):121.

Ye, M., C. Wei., A. Khalid., Q. Hu., R. B. Dai and Z. Wang. 2020. Effect of Bacillus velezensis to substitute in-feed antibiotics on the production, blood biochemistry and egg quality indices of laying hens. BMC Vet. Res., 16(1):1-8. 